\title{
Entomopathogens in conjunction with imidacloprid could be used to manage wireworms (Coleoptera: Elateridae) on spring wheat
}

\section{Authors: Frank B. Antwi, Govinda Shrestha, Gadi V. P. Reddy, Stefan T. Jaronski}

This is a postprint of an article that originally appeared in Canadian Entomologist on February 2018. The final version can be found at https://dx.doi.org/10.4039/tce.2017.58.

Antwi, Frank B., Govinda Shrestha, Gadi V. P. Reddy, and Stefan T. Jaronski. "Entomopathogens in conjunction with imidacloprid could be used to manage wireworms (Coleoptera: Elateridae) on spring wheat." Canadian Entomologist 150, no. 1 (February 2018): 124-139. DOI: 10.4039/ tce.2017.58. 


\title{
Entomopathogens in conjunction with imidacloprid could be used to manage wireworms (Coleoptera: Elateridae) on spring wheat
}

\author{
Frank B. Antwi, Govinda Shrestha, Gadi V.P. Reddy, ${ }^{1}$ Stefan T. Jaronski
}

\begin{abstract}
We examined the effect of biopesticides used alone, mixed with other biopesticides, or in conjunction with an imidacloprid against wireworms (Coleoptera: Elateridae) in spring wheat Triticum aestivum Linnaeus (Poaceae) (variety: Duclair). The study was conducted at Ledger and Valier, Montana, United States of America in 2015 and 2016. Ten biopesticides (spinosad, azadirachtin, pyrethrin, Beauveria bassiana (Balsamo-Crivelli) Vuillemin (Fungi: Clavicipitaceae) GHA (Mycotrol), B. bassiana ANT-03 (BioCeres), Chromobacterium subtsugae Martin et al. (Bacteria: Neisseriaceae), Burkholderia Yabuuchi et al. (Burkholderiaceae) species, Metarhizium brunneum Petch (Fungi: Clavicipitaceae) ESC1 (MbESC1), and M. brunneum F52 (MetF52) as microsclerotial and corn grit-based granules) were tested in addition to thimet and imidacloprid. Treatment efficacy was based on plant stand protection, wireworm populations, and yield. In 2015, there was considerable variation between sites in treatment efficacy. Mycotrol, BioCeres, MetF52 + spinosad, and MetF52 + imidacloprid applications protected seedlings from wireworm damage better than the control at Ledger, while only MetF52 at Valier. Wireworm populations were significantly higher with Mycotrol, spinosad, MetF52 + spinosad, MbESC1 (25 g/L), and MetF52 treatments, compared with control, at 14 and 28 days post application at Ledger, but without effect at Valier, 2015. We found significantly higher yield in plots treated with imidacloprid + MetF52 and Mycotrol + azadirachtin (Xpulse) compared with control at Ledger. In 2016, no significant treatment effects were observed at either site. In summary, this study provides insight on what treatments should be explored in more detail despite variable results.
\end{abstract}

\section{Introduction}

Wireworms, the larvae of click beetles (Coleoptera: Elateridae), are significant economic soil-dwelling pests in temperate and subtropical areas of the world (Thomas 1940; Jackson et al. 2000; Marske and Ivie 2003; Vernon et al. 2008; Traugott et al. 2015). Wireworm larvae can persist in the soil for several years and are often present in agricultural fields at planting (Thomas 1940; Jackson et al. 2000). Wireworms are generalists and feed on a wide variety of field and vegetable crops e.g., cereal, potato, sugarbeet, carrot, sugar cane, and soft roots. They inflict damage to seeds, root, stems, tubers, or other plant parts by feeding, chewing, or drilling into below-ground plant tissues and structures, thereby enhancing plant diseases, stopping plant growth, or killing plants completely (Thomas 1940; Keiser et al. 2012). Wireworms also cause damage to the stems later in the growing season, which stimulates excessive tillering and inhibits wheat head formation. Wireworm injury can cause wilting, stunting, crop thinning, delay in plant maturation, and seedling death, which leads to yield reduction and affects crop value (Parker and Howard 2001; Barsics et al. 2013; Ritter and Richter 2013; Vernon and van Herk 2013; van Herk and Vernon 2014). When wireworm populations are extremely high, entire fields may be lost (Popov et al. 2001; Willis et al. 2010). In many fields, wireworm infestation results in 
an uneven plant stand, which allows weeds to outcompete the crop using up available moisture and preventing or lessening the normal tillering of adjacent uninjured plants (Thomas 1940).

The soil-dwelling nature of wireworms usually makes it difficult to estimate their numbers, which in turn hinders accurate forecasting of likely plant damage or crop loss. Because of this, wireworms are often managed preventively with insecticides applied at planting (Potter et al. 1996; Wilde et al. 2004). Historically, wireworms have been controlled with inexpensive broad-spectrum insecticides (e.g., organochlorines, organophosphates, and carbamates). However, most of these pesticides have either been cancelled or restricted worldwide due to environmental and health concerns (Vernon et al. 2008; Reddy and Tangtrakulwanich 2014), and, consequently, wireworm damage is currently increasing in the United States of America, Canada, and other parts of the world. Current chemical control relies on the use of neonicotinoids (principally imidacloprid), used as seed treatments, to provide seed and foliar protection for several weeks after planting. Neonicotinoids are widely used for control for many crop pests due to the low rates required and long residual activity of the compound (Nault et al. 2004, 2006; Koch et al. 2005; Parker 2005; Elliott et al. 2008; Kuhar and Alvarez 2008). These compounds, however, repel wireworms not kill them, eventually leaving populations essentially unaffected. These pesticides have further adverse effects on the environment, especially non-target organisms (Desneux et al. 2007; Wilde et al. 2007).

For this reason, there is a need to develop other alternative control options, such as environmentally safe biopesticides that might be used alone, combined with other biopesticides, or used in conjunction with a conventional pesticide. The biopesticides include the use of naturally derived compounds from microbes or plants (e.g., spinosyns, azadirachtin, and pyrethrins), living organisms (e.g., insect pathogenic fungi, Beauveria bassiana (Balsamo-Crivelli) Vuillemin (Fungi: Clavicipitaceae) and Metarhizium anisopliae (Metchnikoff) Sorokin sensu lato (Fungi: Clavicipitaceae), or combined formulations of these agents (Chandler et al. 2011; Reddy and Antwi 2016; Reddy et al. 2016). Such products are usually considered low-risk agents with low mammalian toxicity as well as minimal impact on non-target organisms.
Laboratory studies have examined the effect of different isolates and strains of Beauveria Vuillemin and Metarhizium Sorokīn on mortality in two wireworm species: Agriotes lineatus (Linnaeus) and A. obscurus (Linnaeus) (Coleoptera: Elateridae) (Kabaluk et al. 2005; Ericsson et al. 2007; Ansari et al. 2009). Under laboratory conditions, the combined use of $M$. anisopliae and spinosyn increased mortality of these two species (A. lineatus and A. obscurus), compared with either one used alone (Ericsson et al. 2007). Under field conditions in Canada, Kabaluk and Ericsson (2007) found that the use of field corn (Zea mays Linnaeus; Poaceae) seed treated with M. brunneum Petch (F52) conidia significantly enhanced corn yield compared with an untreated control, while no effect of spinosyn alone or in combination with this fungus was found in corn fields infested with A. obscurus (Kabaluk and Ericsson 2007). In Germany and Italy, Ladurner et al. (2009) tested several biopesticide products alone or in combination with synthetic insecticides in potato (Solanum tuberosum Linnaeus; Solanaceae) fields and found another B. bassiana, strain ATCC 74040 , to be a promising agent for the management of $A$. obscurus.

However, the potential value of biopesticides for management of other wireworms, such as Limonius californicus (Mannerheim) and Hypnoidus bicolor (Eschscholtz) (Coleoptera: Elateridae), common in Montana, is poorly understood. Except for two initial studies by Tharp et al. (2005) and Reddy et al. (2014), who found an effect on these wireworm species with insect pathogenic fungi applied as seed treatments in potato crops and spring wheat, respectively. Insect pathogenic fungus use against wireworm management in Montana spring wheat production in one of the studies was encouraging (Reddy et al. 2014). Their study indicated that three insect pathogenic fungi (M. brunneum F52, B. bassiana GHA, and $M$. robertsii Bischoff et al. DWR 346) applied as seed treatments were effective in controlling $L$. californicus and $H$. bicolor in spring wheat. All three fungi, when applied as granules in furrow or as banded soil drenches, significantly increased the plant stand and yields under moderate wireworm pressure, supporting their value in the management of this pest. However, environmental factors such as temperature and soil moisture are likely to influence the fungal efficacy rate because higher temperature and 
lower moisture can often reduce fungal germination rate and thereby reducing efficacy (Jaronski 2010; Shrestha et al. 2015). It was therefore necessary to explore other biopesticides along with these previously used fungal agents for wireworm management in Montana. In addition, if any biopesticides were found to be compatible with the currently available imidacloprid insecticide for wireworm management, it may reduce the application rates and eventually cost less for the growers.

The aim of this two-year study was to evaluate the ability of several biopesticides used alone, mixed with other biopesticides, or in conjunction with a conventional pesticide (imidacloprid), to manage wireworms in Montana spring wheat Triticum aestivum Linnaeus (Poaceae) (variety: Duclair). The efficacy of biopesticide treatments was assessed based on plant stand protection, effects on larval wireworm populations, and grain yield.

\section{Materials and methods}

\section{Study sites}

Before starting our experiments, we sampled extensively for wireworms at each farm site using soil sampling bait trap method (Reddy et al. 2014) to confirm the presence of adequate densities of wireworms. The experiments were carried out in two spring wheat fields, one each at Ledger (48 $\left.18^{\prime} 26.9244^{\prime \prime N}, 111^{\circ} 51^{\prime} 34.4376^{\prime \prime} \mathrm{W}\right)$ and Valier (48 $\left.18^{\prime} 37.4148^{\prime \prime} \mathrm{N}, 112^{\circ} 25^{\prime} 19.0956^{\prime \prime} \mathrm{W}\right)$, in the Golden Triangle area of Montana from April to September in 2015 and 2016. Experimental plots were seeded on 16 April and 16 May in 2015 and 2016, respectively, at the Ledger location and on 28 April and 31 May in 2015 and 2016, respectively, at the Valier location. Both sites had the same cropping history (growing cereal crops mainly year after year) and the wireworm incidence was from moderate to high levels.

The hard red spring wheat variety "Duclair" (Lanning et al. 2011) was seeded at both locations at a rate of 22 seeds per $30 \mathrm{~cm}$ with a four-row plot drill spaced $0.3 \mathrm{~m}$. Before seeding, the herbicide glyphosate (RT3; Monsanto Company, St. Louis, Missouri, United States of America) was applied at the rate of $2.5 \mathrm{~L} / \mathrm{ha}$ for weed control, following local farming practices. Fertiliser (N, P, and $\mathrm{K}$ ) was applied at a ratio of
$224.2,0$, and $22.4 \mathrm{~kg} /$ ha by broadcast application during planting, and an additional fertiliser application $(\mathrm{N}, \mathrm{P}$, and $\mathrm{K}$ at a ratio of $12.3,25.2$, and $0 \mathrm{~kg} / \mathrm{ha}$ ) was applied through the seed plot drill at seeding. The experimental plots received $5 \mathrm{~cm}$ of water via overhead irrigation 30 days after treatment in the all sites.

\section{Experimental design}

In both years (2015 and 2016), the experimental design was a randomised complete block design (RCBD) with four replications per treatment. The number of treatments were 17 and 12 respectively in 2015 and 2016. Plots were $3.6 \times 1.2 \mathrm{~m}$, separated by $0.60 \mathrm{~m}$ buffer zones to avoid cross contamination of treatments. The numbers of plant stand, wireworms in the bait traps, and the seed yield in each plot were recorded to assess the effectiveness of each treatment.

\section{Biopesticide product application}

Biopesticide or synthetic pesticide product rates were based on the respective manufacturers' recommendations (see Tables 1-2 for 2015 and 2016, respectively). Some of the treatments and formulations that failed to reduce wireworm numbers or to protect plant stands in 2015 were not included in 2016 (Table 2). In 2015 and 2016, imidacloprid (as Gaucho 600, Bayer Crop Science, Raleigh, North Carolina, United States of America) was applied as a seed treatment. No fungicide was added to the seeds treated with imidacloprid. Imidacloprid $+B$. bassiana GHA (Mycotrol ESO, LAM International, Butte, Montana, United States of America) and imidacloprid $+M$. brunneum F52 (Met52 EC, Novozymes Biologicals, Salem, Virginia, United States of America) treatments were applied to the rows by spraying Mycotrol and Met52 as a soil drench to the base of plants grown from seed treated with imidacloprid. The granular formulation of the entomopathogen $B$. bassiana ANT-03 (BioCeres G; Anatis Bioprotection, St.-Jacques-le-Mineur, Québec, Canada) was applied by placing $21.6 \mathrm{~g}$ of product to each row by hand. In 2016, Gaucho and a heat-killed formulation of the bacterium Burkholderia Yabuuchi et al. (Burkholderiaceae) strain A396 (Venerate $\mathrm{XC}$ ) were applied as seed treatments. A formulation of the bacterium Chromobacterium subtsugae Martin et al. (Bacteria: Neisseriaceae) 
Table 1. Materials and rates of application in each treatment, 2015.

\begin{tabular}{|c|c|c|c|}
\hline Treatment & Active ingredient & Rate $(\mathrm{mL} / \mathrm{L})$ & Source \\
\hline Water $(\mathrm{W})$ & - & - & - \\
\hline Gaucho $600 *(\mathrm{G})$ & Imidacloprid & $70.98 / 45.35 \mathrm{~kg}$ seed & Bayer Crop Science, Raleigh, North Carolina, United States of America \\
\hline Entrust $\mathrm{WP}^{\dagger}(\mathrm{E})$ & Spinosad & 0.091 & Dow AgroSciences LLC, Indianapolis, Indiana, United States of America \\
\hline M-1 (25 g/L) (M-1) & $\begin{array}{l}\text { Metarhizium brunneum } \\
\text { ESC1 }\end{array}$ & 0.09 & LidoChem, Hazlet, New Jersey, United States of America \\
\hline Met52 EC (Met) & Metarhizium brunneum F52 & 0.72 & Novozymes Biologicals, Salem, Virginia, United States of America \\
\hline Mycotrol ESO (My) & Beauveria bassiana GHA & 0.72 & LAM International, Butte, Montana, United States of America \\
\hline Mycotrol ESO + Met52 EC (My + Met) & B. bassiana + M. brunneum & $0.36+0.36$ & LAM International, Butte, Montana, United States of America \\
\hline Mycotrol ESO + Aza-Direct (My + Az) & B. bassiana + Azadiracthin & $0.36+0.72$ & LAM International, Butte, Montana, United States of America \\
\hline Mycotrol ESO + Entrust $(\mathrm{My}+\mathrm{E})$ & B. bassiana + Spinosad & $0.36+0.0455$ & LAM International, Butte, Montana, United States of America \\
\hline Mycotrol ESO + Gaucho $600^{\ddagger}(\mathrm{My}+\mathrm{G})$ & B. bassiana + Imidacloprid & $0.36+35.49$ & LAM International, Butte, Montana, United States of America \\
\hline Met52 EC + Aza-Direct $(\mathrm{Met}+\mathrm{Az})$ & M. brunneum F52 + Azadiracthin & $0.36+0.72$ & LAM International, Butte, Montana, United States of America \\
\hline Met52 EC + Entrust $($ Met + E) & M. brunneum F52 + Spinosad & $0.36+0.0455$ & LAM International, Butte, Montana, United States of America \\
\hline Met52 EC + Gaucho $600($ Met + G) & M. brunneum F52 + Imidacloprid & $0.36+0.0785$ & LAM International, Butte, Montana, United States of America \\
\hline M-2 (50 g/L M-2) & Metarhizium brunneum ESC1 & 0.18 & LidoChem, Hazlet, New Jersey, United States of America \\
\hline Xpectro OD (XPE) & Pyrethrin + B. bassiana GHA & 2.5 & LAM International, Butte, Montana, United States of America \\
\hline BioCeres $\mathrm{GR}^{\S}(\mathrm{Bi})$ & B. bassiana ANT-03 & 20 & Anatis Bioprotection, St.-Jacques-le-Mineur, Québec, Canada \\
\hline Xpulse OD (XPU) & B. bassiana $\mathrm{GHA}+$ Azadirachtin & 0.72 & LAM International, Butte, Montana, United States of America \\
\hline
\end{tabular}

\footnotetext{
* Gaucho 600, seed treatment application rate unit $(\mathrm{mL} / 45.35 \mathrm{~kg}$ seed).

${ }^{\dagger}$ Entrust WP, application rate unit $(\mathrm{g} / \mathrm{L})$.

Gaucho 600, seed treatment application rate unit $(35.49 \mathrm{~mL} / 45.35 \mathrm{~kg}$ seed $)$.

${ }^{\S}$ BioCeres GR, application rate unit $\left(20 \mathrm{~g} / \mathrm{m}^{2}\right)$.
} 


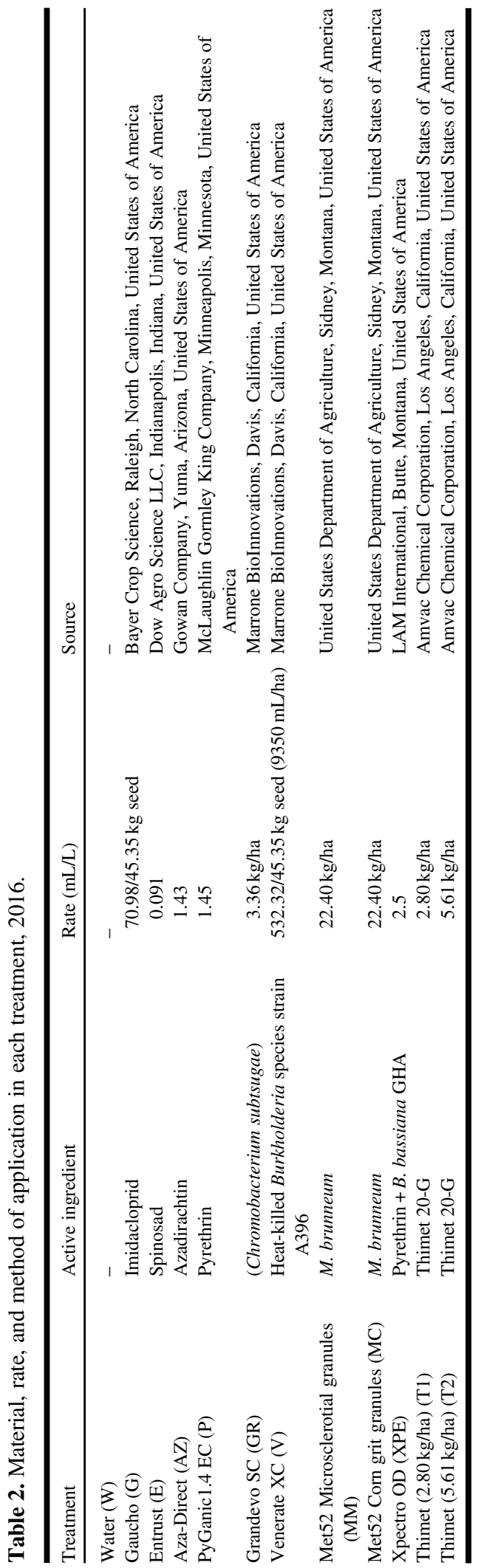

(Grandevo SC, Marrone BioInnovations, Davis, California, United States of America), F52 formulated as microsclerotia or on a corn grit granule, and the organophosphate insecticide phorate (Thimet 20-G) were all applied in furrow.

All other treatment combinations used in 2015 and 2016 (see Tables 1-2) were tank mixed and applied to rows as a soil drench. A 92-mL spray suspension was applied per row in each application. Spray treatments were applied to plots with a SOLO four-gallon backpack sprayer \#425 (SOLO; Newport News, Virginia, United States of America) with a flat spray nozzle, $144.8-\mathrm{kPa}$ valve $(21.0 \mathrm{psi})$, and calibrated at $816.89 \mathrm{~L} / \mathrm{ha}$. Spray applications were made 14 days after seeding.

\section{Plant stand counts}

The number of emerged wheat seedlings was determined along a 1-m strip in the middle of the centremost two rows of each plot as a measure of initial plant stand protection. The starting and ending points of the sample areas were marked with plastic labels so that the same seedlings could be recounted before and after treatments. In both 2015 and 2016, wheat seedlings were counted again 28 days after treatment application.

\section{Larval wireworm sampling}

"Stocking bait" traps, described in (Reddy et al. 2014), were used to detect wireworms and to estimate their relative abundance. The stocking bait traps were placed evenly along the centre of each plot, spaced $1 \mathrm{~m}$ apart. To make the baits, about $90 \mathrm{~g}$ of wheat seed was placed in a nylon stocking, which was then tied shut with a string, leaving a tail end of about $30 \mathrm{~cm}$. These traps were immersed in water for 24 hours to stimulate the grain to start germinating before being placed in holes $7-15 \mathrm{~cm}$ deep and positioned so as to maximise the contact of the grain mixture with the soil as much as possible. The strings were left above the soil surface to help locate the traps later. The traps were then covered with about $3-5 \mathrm{~cm}$ of soil. A $12 \times 12 \mathrm{~cm}$ piece of black poly ethylene was placed over the covered holes and four metal pegs were used to secure these pieces of polythene to the soil. This system is required to avoid entry by ground squirrels (G.V.P. Reddy, personal observation).

In 2015, three stocking traps, spaced $1 \mathrm{~m}$ apart, were placed in the middle row of each plot. 
These traps were deployed one week before the spray applications. Just before treatments were applied, one trap from each plot was removed to estimate the pre-treatment wireworm density in plots (one bait per plot, with four replicates of each treatment). The second and third traps were sequentially removed 14 and 28 days after treatment. Larvae found in traps were counted in the laboratory. A similar procedure was used for 2016 wireworm samplings, except that just two stocking bait traps per plot were used, with one sampled before treatments and the other 28 days after treatments. Wireworm species were identified in 2016 using morphological keys developed by Etzler et al. (2014).

\section{Crop yield}

A Hege 140 plot combine was used to sample the plots for yield assessment. Wheat seeds were cleaned with a seed processor (Almaco, Nevada, Iowa, United States of America) and weighed on a scale to determine yield per plot at the Western Triangle Agricultural Research Center (WTARC) seed laboratory in Conrad, Montana.

\section{Statistical analyses}

The data were analysed using SAS 9.4 (SAS Institute 2015). Analysis of covariance was used to determine the impact of treatments on wireworm larval population and yield levels. Treatment differences were assessed using Fisher's least significant (LSD) test. Paired $t$-test was used to assess the effect of treatment on plant stand counts before and after the treatment application within each group. To compare among the treatments for plant stand counts, the plant survival percentage was calculated as (number of plant counts after treatment application/total number of plant counts before treatment application) $\times 100$, prior to data subjected to analysis. One-way analysis of variance was used to determine the treatment effects on plant survival percentage followed by post hoc Tukey test for means comparisons.

\section{Results}

\section{Plant stand count}

In the 2015 Ledger study site, the paired $t$-test result showed that there was a significant reduction in plant stand counts after the treatment applications on nearly all treated groups, except for Gaucho $600(\mathrm{G})$, Met52 EC+Entrust WP $(\mathrm{Met}+\mathrm{E})$, and BioCeres GR (Bi)-treated plots (Table 3). In contrast, regardless of treatments, there was a significant reduction in plant stand counts after treatment application at the Valier study site (Table 3 ).

When comparing the treatment groups, the 2015 study showed significant effects on plants survival percentage after treatment applications at the Ledger $(F=3.50 ; \quad \mathrm{df}=16, \quad 119 ; \quad P=0.001)$ and Valier $(F=2.00 ; \quad \mathrm{df}=16, \quad 119 ; \quad P=0.01) \quad$ study sites.

Among treatments, significantly higher mean plant survival percentage ( \pm standard error) were observed at the Ledger location for Mycotrol ESO (My) (78.91 \pm 6.99$)$, Met52 EC+Entrust WP (Met+E) (76.57 \pm 7.01$)$, Gaucho 600 (G) (73.93 \pm 7.03$)$, Met52 EC+Gaucho $600($ Met + G) $(71.24 \pm 2.57)$, and BioCeres GR (Bi) $(70.61 \pm 7.41)$ treatments than in water control (W) $(40.05 \pm 2.12)$ (Fig. 1).

Other treatments were not significantly different from water control (Fig. 1). At the Valier location,

Met52 EC (Met) treatment had significantly higher mean percentage plant survival $( \pm$ standard error) $(65.86 \pm 5.02)$ as compared with water control (W) $(41.18 \pm 1.96)$ (Fig. 1).

In contrast to the 2015 study, there was no significant decline in nearly all treated groups when plant stand counts compared between before and after the treatment application within each group in the 2016 study (Table 4). Except water (W), Gaucho 600 (G), Grandevo SC (GR), and Met52 microsclerotial granules (MM) treated groups at the Ledger, and water (W) and Thimet $20-\mathrm{G}(\mathrm{T} 2)(5.61 \mathrm{~kg} / \mathrm{ha})$ at the Valier were significantly different (Table 4). Similar pattern was also observed when mean plant survival percentage were compared among treatment groups. No significant differences recorded on survival percentage at Ledger $(F=1.00 ; \mathrm{df}=11,84$; $P=0.44)$ and Valier $(F=1.81 ; \mathrm{df}=11,84$; $P=0.06$ ) locations (Fig. 2). Consequently, the 2016 study indicated non-significant effect of biopesticide treatments on plant stand count at both field locations.

\section{Wireworm populations}

Wireworms were successfully captured in baited stocking traps in all treatments regardless of location, except in the Mycotrol ESO + Entrust $\mathrm{WP}(\mathrm{My}+\mathrm{E})$ treatment in 2015 pre-treatment sampling at Ledger. The mean number of 
Table 3. Paired $t$-test comparisons of plant stand count recorded before and 28 days after biopesticides or synthetic pesticide application at the two study locations of Montana, 2015. SE, standard error.

\begin{tabular}{|c|c|c|c|c|}
\hline \multirow[b]{2}{*}{ Treatments } & \multicolumn{2}{|c|}{ Plant stand count (mean \pm SE) } & \multicolumn{2}{|c|}{ Statistical values } \\
\hline & Pre-treatment & Post treatment & $T$ & $P$ \\
\hline \multicolumn{5}{|l|}{ Ledger } \\
\hline W & $36.00 \pm 4.45$ & $14.63 \pm 1.63$ & 6.73 & $<0.0001$ \\
\hline $\mathrm{G}$ & $36.11 \pm 3.51$ & $23.89 \pm 2.89$ & 2.40 & 0.05 \\
\hline E & $30.25 \pm 2.43$ & $11.38 \pm 1.25$ & 4.95 & 0.003 \\
\hline M-1 & $26.00 \pm 2.69$ & $15.25 \pm 2.40$ & 3.64 & 0.008 \\
\hline M-2 & $36.00 \pm 3.33$ & $12.50 \pm 3.21$ & 4.97 & 0.005 \\
\hline Met & $30.38 \pm 4.05$ & $12.75 \pm 2.96$ & 4.00 & 0.005 \\
\hline Мy & $28.13 \pm 2.30$ & $20.38 \pm 2.80$ & 2.75 & 0.01 \\
\hline My + Met & $27.50 \pm 2.54$ & $12.50 \pm 1.70$ & 8.56 & $<0.0001$ \\
\hline $\mathrm{My}+\mathrm{Az}$ & $28.38 \pm 3.26$ & $16.75 \pm 1.95$ & 3.95 & 0.01 \\
\hline My +E & $27.38 \pm 3.26$ & $13.25 \pm 2.60$ & 3.62 & 0.01 \\
\hline $\mathrm{My}+\mathrm{G}$ & $25.50 \pm 1.97$ & $14.13 \pm 2.02$ & 5.38 & 0.001 \\
\hline $\mathrm{Met}+\mathrm{Az}$ & $26.50 \pm 2.65$ & $11.13 \pm 1.42$ & 9.04 & $<0.0001$ \\
\hline Met $+\mathrm{E}$ & $25.50 \pm 3.09$ & $19.63 \pm 3.84$ & 0.91 & 0.39 \\
\hline Met $+\mathrm{G}$ & $28.88 \pm 3.14$ & $20.38 \pm 2.34$ & 5.93 & 0.001 \\
\hline XPE & $26.13 \pm 2.61$ & $14.13 \pm 2.07$ & 3.9 & 0.001 \\
\hline $\mathrm{Bi}$ & $20.13 \pm 2.56$ & $15.50 \pm 2.08$ & 1.73 & 0.12 \\
\hline XPU & $31.25 \pm 2.07$ & $18.00 \pm 2.06$ & 2.33 & 0.04 \\
\hline \multicolumn{5}{|l|}{ Valier } \\
\hline W & $29.88 \pm 3.85$ & $13.63 \pm 2.00$ & 14.02 & $<0.0001$ \\
\hline G & $56.63 \pm 3.95$ & $20.25 \pm 2.07$ & 10.32 & $<0.0001$ \\
\hline E & $35.13 \pm 3.36$ & $15.25 \pm 1.32$ & 5.43 & 0.001 \\
\hline M-1 & $26.38 \pm 3.24$ & $10.63 \pm 1.75$ & 4.58 & 0.002 \\
\hline M-2 & $34.13 \pm 6.26$ & $15.88 \pm 2.09$ & 3.62 & 0.01 \\
\hline Met & $27.88 \pm 2.79$ & $16.00 \pm 2.20$ & 2.59 & 0.04 \\
\hline My & $29.13 \pm 3.72$ & $11.25 \pm 1.54$ & 4.19 & 0.004 \\
\hline My + Met & $40.75 \pm 1.92$ & $20.25 \pm 2.97$ & 5.20 & 0.001 \\
\hline $\mathrm{My}+\mathrm{Az}$ & $41.38 \pm 4.79$ & $16.25 \pm 1.63$ & 4.15 & 0.004 \\
\hline $\mathrm{My}+\mathrm{E}$ & $46.38 \pm 3.16$ & $17.38 \pm 1.36$ & 9.15 & $<0.0001$ \\
\hline $\mathrm{My}+\mathrm{G}$ & $40.38 \pm 2.30$ & $20.00 \pm 1.51$ & 9.31 & $<0.0001$ \\
\hline $\mathrm{Met}+\mathrm{Az}$ & $28.75 \pm 2.27$ & $13.13 \pm 1.86$ & 7.11 & 0.0001 \\
\hline Met + E & $29.38 \pm 2.15$ & $12.63 \pm 1.72$ & 5.55 & 0.001 \\
\hline $\mathrm{Met}+\mathrm{G}$ & $39.38 \pm 3.51$ & $14.38 \pm 1.72$ & 7.98 & $<0.0001$ \\
\hline XPE & $28.88 \pm 3.87$ & $14.50 \pm 1.57$ & 3.28 & 0.01 \\
\hline $\mathrm{Bi}$ & $26.63 \pm 1.34$ & $12.63 \pm 2.24$ & 5.32 & 0.001 \\
\hline XPU & $32.13 \pm 4.34$ & $15.50 \pm 2.20$ & 3.57 & 0.01 \\
\hline
\end{tabular}

W, water; G, Gaucho 600; E, Entrust WP; M-1, M-1 (25 g/L); M-2, M-2 (50 g/L); Met, Met52 $\mathrm{EC}$; My, Mycotrol ESO; My+ Met, Mycotrol ESO+Met52 EC; My+ Az, Mycotrol ESO+ Aza-Direct; My + E, Mycotrol ESO + Entrust WP; My + G, Mycotrol ESO + Gaucho 600; Met + Az, Met52 EC + Aza-Direct; Met + E, Met52 EC + Entrust WP; Met + G, Met52 EC + Gaucho 600; XPE, Xpectro OD; Bi, BioCeres; XPU, Xpulse OD.

wireworms per baited trap ranged from 0.00 to 3.00 and 1.75 to 5.25 , respectively, at the Ledger and Valier (Table 5). In 2016 pre-treatment sampling, similar mean numbers of wireworms $(0.25-$ 4.25) were captured in baited stocking traps at the Ledger location (except that no wireworms were found in plots designated for Thimet 20-G (T1; $2.79 \mathrm{~kg} / \mathrm{ha}$, while very few wireworms $(<0.80)$ were found at Valier (Table 6).

In 2015 significant differences in overall wireworm populations were observed at Ledger $(F=1.56 ;$ df $=17,118 ; P<0.05)$, but not at 
Fig. 1. Mean percentage survival of wheat plants ( \pm standard error (SE)) 28 days after biopesticide or synthetic insecticide application at the Ledger and Valier of Montana, 2015. The number of replicates per treatment was four and each replicate has two repetitions. Bars bearing the same letters are not significantly different (Tukey test, $P>0.05)$. W, water; G, Gaucho 600; E, Entrust WP; M-1, M-1 (25 g/L); M-2, M-2 (50 g/L); Met, Met52 EC; My, Mycotrol ESO; My + Met, Mycotrol ESO + Met52 EC; My + Az, Mycotrol ESO+ Aza-Direct; My + E, Mycotrol ESO + Entrust WP; My+ G, Mycotrol ESO + Gaucho 600; Met + Az, Met52 EC + Aza-Direct; Met + E, Met52 EC+Entrust WP; Met+G, Met52 EC+Gaucho 600; XPE, Xpectro OD; Bi, BioCeres GR; XPU, Xpulse OD.
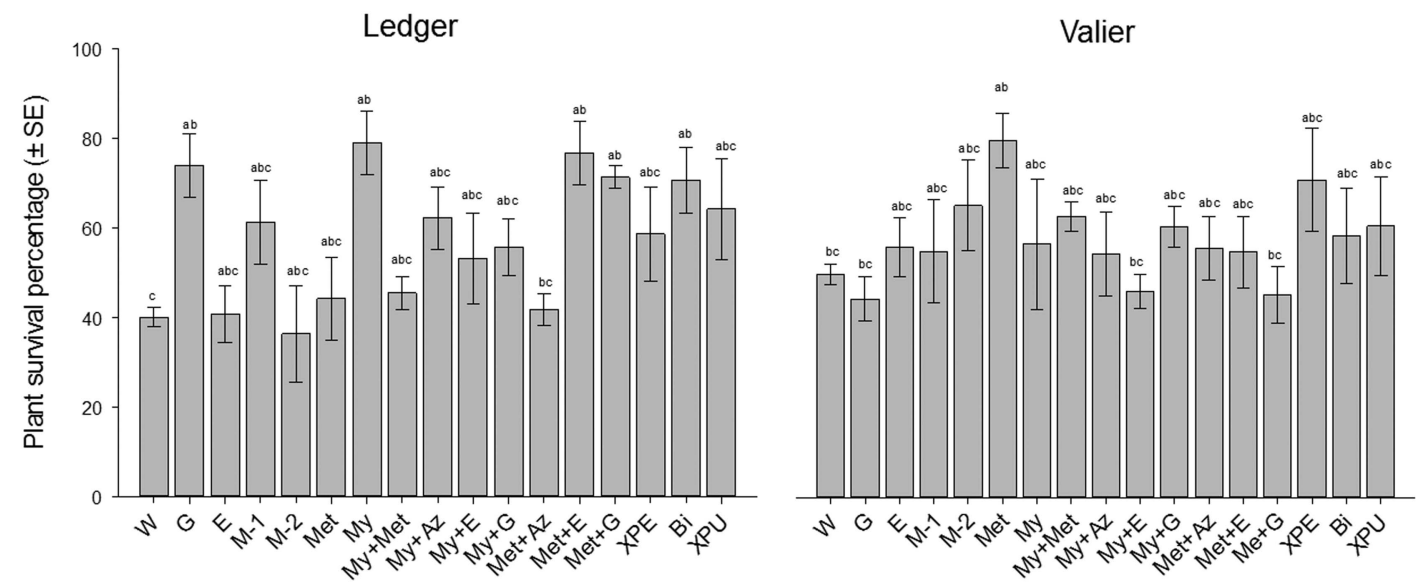

Valier $\quad(F=0.59 ; \quad \mathrm{df}=17, \quad 118 ; \quad P>0.05)$ (Table 5). Unexpectedly, the mean wireworm populations ( \pm standard error) at Ledger were significantly higher in some of the biopesticide treatment plots compared with the water control at 14 days $(F=1.01 ; \mathrm{df}=16,51 ; P<0.05)$ and 28 days $(F=1.70 ; \mathrm{df}=16,51 ; P<0.05)$. The Met52 EC + Entrust WP (Met +E) $(5.50 \pm 2.18)$, M-1 (25 g/L) $(5.00 \pm 1.68)$, and Entrust WP (E) $(4.00 \pm 0.71)$ treatments had significantly higher wireworm populations than did the water control treatment $(1.63 \pm 0.73) 14$ days after treatment (Table 5). At 28 days, only the Mycotrol ESO (My) treatment had a significantly higher wireworm population $(4.00 \pm 2.83)$ than did the water control (1.00 \pm 0.57$)$ (Table 5).

In 2016, treatments had no significant effect on wireworm populations 28 days after treatment: Valier $(F=1.12 ; \mathrm{df}=11,35 ; P>0.05)$, Ledger $(F=1.20 ; \mathrm{df}=11,35 ; P>0.05)$ (Table 6). Across the treatments, the mean number of wireworms per bait trap varied from 0.00 to 0.75 and 0.00 to 1.25, respectively, at Ledger and Valier (Table 6).

\section{Wireworm species composition}

In the 2016 study, wireworm species collected from Valier and Ledger were L. californicus,
H. bicolor, and Aeolus mellilus Say irrespective of study locations. In both locations, H. bicolor was the most predominant species followed by L. californicus and A. mellilus at both before and 28 days after treatment. The total number of $H$. bicolor, L. californicus, and A. mellilus individuals recorded at Ledger were 57, 8, and 2, respectively, and the comparing value for Valier were 24,12 , and 4 , respectively.

\section{Crop yield}

Average wheat grain yield for 2015 ranged from 3436 to $4743 \mathrm{~kg} / \mathrm{ha}$ and 2448 to $3541 \mathrm{~kg} / \mathrm{ha}$ respectively, at the Ledger and Valier locations (Fig. 3). The corresponding values for 2016 were $1017-1867 \mathrm{~kg} / \mathrm{ha}$ and $514-762 \mathrm{~kg} / \mathrm{ha}$, respectively (Fig. 4). Treatments showed significant impact on grain yield in 2015 at both Ledger $(F=1.04 ; \quad \mathrm{df}=16,51 ; P<0.05)$ and Valier $(F=0.81 ; \mathrm{df}=16,51 ; P<0.05)$, while in 2016 a significant effect of treatments was observed at Ledger $(F=1.26$; df $=11,36 ; P<0.05)$ but not Valier $(F=0.51$; df $=11,36 ; P>0.05)$ (Fig. 4).

At Ledger in 2015, yields in the Xpulse (XPU) $(4743.70 \pm 363.12 \mathrm{~kg} / \mathrm{ha})$ and Met52 EC+ Gaucho 600 (Met + G) $(4420 \pm 49.65 \mathrm{~kg} / \mathrm{ha})$ plots were significantly higher than in the control 
Table 4. Paired $t$-test comparisons of plant stand count recorded before and 28 days after biopesticides or synthetic pesticide application at the two study locations of Montana, 2016. SE, standard error.

\begin{tabular}{|c|c|c|c|c|}
\hline \multirow[b]{2}{*}{ Treatments } & \multicolumn{2}{|c|}{ Plant stand count (mean \pm SE) } & \multicolumn{2}{|c|}{ Statistical values } \\
\hline & Pre-treatment & Post-treatment & $T$ & $P$ \\
\hline \multicolumn{5}{|l|}{ Ledger } \\
\hline W & $50.25 \pm 2.81$ & $33.63 \pm 4.23$ & 2.74 & 0.03 \\
\hline G & $41.38 \pm 2.20$ & $26.38 \pm 4.11$ & 3.89 & 0.006 \\
\hline $\mathrm{E}$ & $46.75 \pm 5.35$ & $29.75 \pm 3.60$ & 2.07 & 0.08 \\
\hline $\mathrm{AZ}$ & $41.00 \pm 2.13$ & $30.38 \pm 6.16$ & 2.40 & 0.05 \\
\hline $\mathrm{P}$ & $41.38 \pm 3.90$ & $28.38 \pm 2.68$ & 2.02 & 0.08 \\
\hline GE & $44.13 \pm 4.80$ & $24.88 \pm 2.33$ & 3.02 & 0.02 \\
\hline V & $47.88 \pm 4.62$ & $39.25 \pm 3.54$ & 1.11 & 0.305 \\
\hline MM & $50.88 \pm 4.95$ & $26.88 \pm 3.20$ & 4.66 & 0.002 \\
\hline $\mathrm{MC}$ & $43.75 \pm 4.66$ & $32.38 \pm 3.70$ & 1.64 & 0.15 \\
\hline XPE & $47.63 \pm 3.99$ & $41.88 \pm 2.57$ & 1.94 & 0.10 \\
\hline $\mathrm{T} 1$ & $43.13 \pm 1.82$ & $35.63 \pm 2.95$ & 1.91 & 0.10 \\
\hline $\mathrm{T} 2$ & $46.63 \pm 2.92$ & $37.75 \pm 2.43$ & 2.24 & 0.07 \\
\hline \multicolumn{5}{|l|}{ Valier } \\
\hline W & $26.75 \pm 2.43$ & $17.13 \pm 2.43$ & 5.07 & 0.001 \\
\hline $\mathrm{G}$ & $22.88 \pm 3.83$ & $18.75 \pm 2.24$ & 1.83 & 0.11 \\
\hline $\mathrm{E}$ & $14.38 \pm 2.33$ & $18.75 \pm 1.19$ & 1.54 & 0.17 \\
\hline $\mathrm{AZ}$ & $20.00 \pm 2.74$ & $15.88 \pm 3.24$ & 0.93 & 0.385 \\
\hline $\mathrm{P}$ & $20.75 \pm 2.84$ & $18.50 \pm 2.33$ & 1.03 & 0.336 \\
\hline GE & $21.38 \pm 2.93$ & $15.00 \pm 2.25$ & 2.08 & 0.08 \\
\hline $\mathrm{V}$ & $14.88 \pm 2.29$ & $19.13 \pm 1.17$ & 1.42 & 0.20 \\
\hline MM & $24.50 \pm 1.81$ & $19.50 \pm 0.93$ & 1.97 & 0.09 \\
\hline $\mathrm{MC}$ & $21.88 \pm 1.29$ & $17.63 \pm 1.18$ & 2.40 & 0.05 \\
\hline XPE & $16.88 \pm 2.07$ & $13.38 \pm 1.19$ & 2.15 & 0.07 \\
\hline $\mathrm{T} 1$ & $18.00 \pm 2.62$ & $17.63 \pm 1.18$ & 0.11 & 0.91 \\
\hline $\mathrm{T} 2$ & $23.25 \pm 2.33$ & $16.25 \pm 1.46$ & 4.53 & 0.003 \\
\hline
\end{tabular}

W, water; G, Gaucho 600; E, Entrust WP; AZ, Aza-Direct; P, PyGanic 1.4 EC; GR, Grandevo SC; V, Venerate XC; MM, Met52 microsclerotial granules; MC, Met52 corn grit granules; XPE, Xpectro OD; T1, Thimet 20-G (2.80 kg/ha); T2, Thimet 20-G (5.61 kg/ha).

treatment $(3498 \pm 484.40 \mathrm{~kg} / \mathrm{ha}) \quad$ (Fig. 3). In contrast, at Valier, grain yields in the Entrust WP (E), Mycotrol + Entrust WP $(\mathrm{My}+\mathrm{E})$, BioCeres GR (Bi), Met52 EC+ Gaucho $600(\mathrm{Met}+\mathrm{G})$, and Met52 EC (Met) treatments were only numerically higher than the control (Fig. 3). At Ledger in 2016, Xpectro OD (XPE), and Met52 Microsclerotial granules (MM) treatments had comparatively higher yields than water control treatment but without significant differences (Fig. 4).

\section{Discussion}

Wireworms are resurging as pests on many crops due to the fact that most pesticides used traditionally for their management have either been withdrawn or restricted due to environmental or health concerns (Adhikari and Reddy 2017). In these two-year field studies, we examined several commercial or experimental biopesticides for their potential to manage wireworms in spring wheat in the Golden Triangle area of Montana. Assessment of efficacy was based on the plant stand protection, wireworm larval populations, and grain yield.

Protecting wheat seedling stands from wireworm feeding in Montana and western Canada is often needed to achieve maximum crop yield (Ester and Huiting 2007; Kabaluk and Ericsson 2007; Vernon et al. 2009; Reddy et al. 2014). Imidacloprid is considered the benchmark pesticide against which to measure wireworm control 
Fig. 2. Mean percentage survival of wheat plants ( \pm standard error (SE)) 28 days after biopesticide or synthetic insecticide application at the Ledger and Valier of Montana, 2016. The number of replicates per treatment was four and each replicate has two repetitions. Bars bearing the same letters are not significantly different (Tukey test, $P>0.05$ ). W, water; G, Gaucho 600; E, Entrust WP; AZ, Aza-Direct; P, PyGanic 1.4 EC; GR, Grandevo SC; V, Venerate XC; MM, Met52 microsclerotial granules; MC, Met52 corn grit granules; XPE, Xpectro OD; T1, Thimet 20-G (2.80 kg/ha; T2, Thimet 20-G (5.61 kg/ha)).
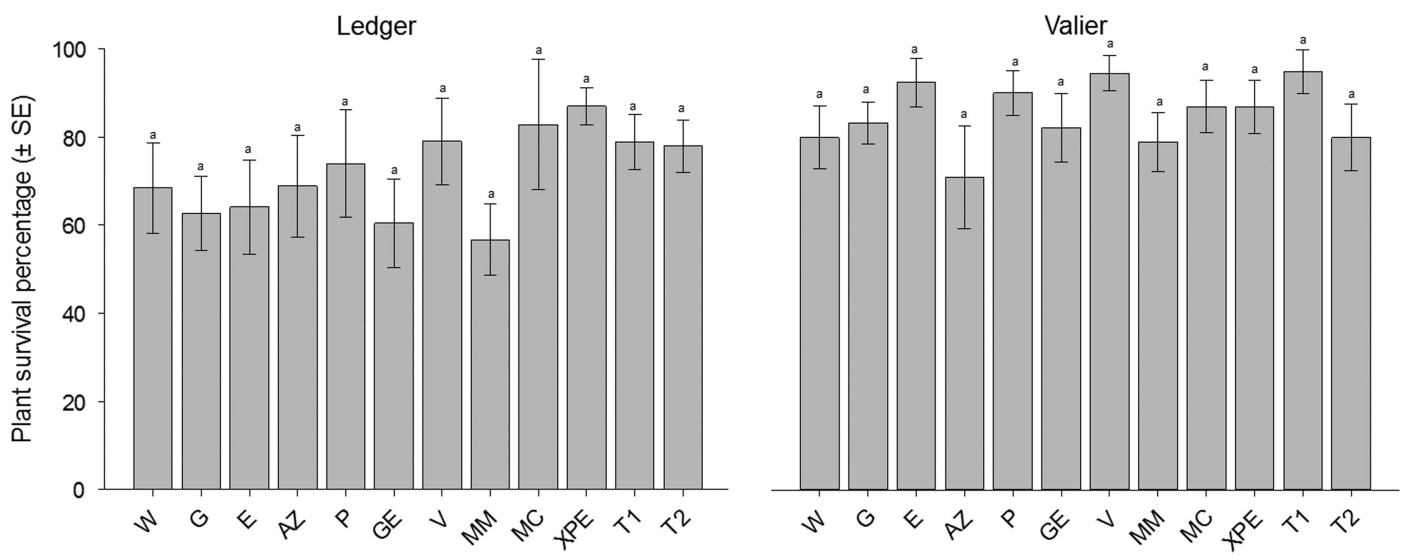

Table 5. Wireworm catch per baited trap in wheat seedling plots treated with biopesticides or synthetic insecticides at the two study locations of Montana, 2015.

\begin{tabular}{|c|c|c|c|c|c|c|}
\hline \multirow[b]{2}{*}{ Treatment } & \multicolumn{3}{|c|}{ Ledger } & \multicolumn{3}{|c|}{ Valier } \\
\hline & $\mathrm{PT}^{*}$ & $14 \mathrm{DPT}^{\dagger}$ & $28 \mathrm{DPT}^{*}$ & $\mathrm{PT}^{*}$ & $14 \mathrm{DPT}^{\dagger}$ & $28 \mathrm{DPT}^{\ddagger}$ \\
\hline W & $3.00 \pm 0.76$ & $1.63 \pm 0.73 \mathrm{~cd}$ & $1.00 \pm 0.57 b$ & $2.13 \pm 1.01$ & $1.13 \pm 0.40 \mathrm{a}$ & $1.13 \pm 0.52 \mathrm{a}$ \\
\hline G & $2.50 \pm 0.96$ & $1.75 \pm 0.48 \mathrm{bcd}$ & $1.00 \pm 0.58 \mathrm{~b}$ & $5.00 \pm 2.16$ & $0.75 \pm 0.48 \mathrm{a}$ & $1.50 \pm 0.65 \mathrm{a}$ \\
\hline E & $0.25 \pm 0.25$ & $4.00 \pm 0.71 \mathrm{ab}$ & $1.00 \pm 0.58 \mathrm{~b}$ & $5.25 \pm 1.31$ & $0.75 \pm 0.48 \mathrm{a}$ & $0.25 \pm 0.25 \mathrm{a}$ \\
\hline M-1 & $2.00 \pm 1.08$ & $5.00 \pm 1.68 \mathrm{ab}$ & $0.75 \pm 0.48 b$ & $4.50 \pm 1.04$ & $1.25 \pm 0.95 \mathrm{a}$ & $0.50 \pm 0.50 \mathrm{a}$ \\
\hline M-2 & $2.00 \pm 2.00$ & $2.25 \pm 1.44 \mathrm{abcd}$ & $2.50 \pm 0.87 a b$ & $4.00 \pm 1.83$ & $0.50 \pm 0.29 a$ & $0.75 \pm 0.75 \mathrm{a}$ \\
\hline Met & $2.00 \pm 1.08$ & $1.75 \pm 1.11 \mathrm{bcd}$ & $1.50 \pm 0.50 \mathrm{ab}$ & $1.75 \pm 1.03$ & $0.25 \pm 0.25 \mathrm{a}$ & $1.00 \pm 0.71 \mathrm{a}$ \\
\hline Мy & $2.00 \pm 1.41$ & $0.25 \pm 0.25 \mathrm{~d}$ & $4.00 \pm 2.83 \mathrm{a}$ & $4.00 \pm 2.00$ & $0.75 \pm 0.25 \mathrm{a}$ & $1.00 \pm 1.00 \mathrm{a}$ \\
\hline My + Met & $1.75 \pm 0.48$ & $2.25 \pm 1.31 \mathrm{abcd}$ & $1.50 \pm 0.96 a b$ & $4.00 \pm 0.71$ & $1.75 \pm 0.63 a$ & $0.50 \pm 0.29 a$ \\
\hline $\mathrm{My}+\mathrm{Az}$ & $0.75 \pm 0.75$ & $1.75 \pm 1.03 \mathrm{bcd}$ & $0.50 \pm 0.50 b$ & $2.75 \pm 0.85$ & $0.75 \pm 0.48 \mathrm{a}$ & $1.25 \pm 0.48 \mathrm{a}$ \\
\hline $\mathrm{My}+\mathrm{E}$ & $0.00 \pm 0.00$ & $3.00 \pm 1.29 \mathrm{abcd}$ & $0.00 \pm 0.00 \mathrm{~b}$ & $1.75 \pm 0.48$ & $0.25 \pm 0.25 \mathrm{a}$ & $1.25 \pm 0.48 \mathrm{a}$ \\
\hline $\mathrm{My}+\mathrm{G}$ & $1.00 \pm 1.00$ & $1.50 \pm 0.65 \mathrm{~cd}$ & $0.75 \pm 0.48 b$ & $3.25 \pm 0.75$ & $0.75 \pm 0.48 \mathrm{a}$ & $1.00 \pm 0.58 \mathrm{a}$ \\
\hline $\mathrm{Met}+\mathrm{Az}$ & $1.00 \pm 0.71$ & $2.25 \pm 1.11 \mathrm{abcd}$ & $1.50 \pm 0.65 \mathrm{ab}$ & $4.00 \pm 1.08$ & $0.25 \pm 0.25 b$ & $1.00 \pm 0.71 \mathrm{a}$ \\
\hline Met + E & $1.50 \pm 0.65$ & $5.50 \pm 2.18 \mathrm{a}$ & $2.50 \pm 1.19 \mathrm{ab}$ & $4.50 \pm 1.71$ & $1.00 \pm 0.58 \mathrm{a}$ & $0.00 \pm 0.00 \mathrm{a}$ \\
\hline Met $+\mathrm{G}$ & $1.50 \pm 1.50$ & $3.25 \pm 1.44 \mathrm{abcd}$ & $0.75 \pm 0.75 b$ & $4.25 \pm 1.11$ & $0.25 \pm 0.25 \mathrm{a}$ & $0.25 \pm 0.25 \mathrm{a}$ \\
\hline XPE & $1.25 \pm 0.75$ & $2.75 \pm 0.48 \mathrm{abcd}$ & $1.25 \pm 0.48 b$ & $2.75 \pm 1.03$ & $0.75 \pm 0.48 \mathrm{a}$ & $0.50 \pm 0.29 a$ \\
\hline $\mathrm{Bi}$ & $1.00 \pm 0.71$ & $2.25 \pm 1.31 \mathrm{abcd}$ & $1.50 \pm 0.96 \mathrm{ab}$ & $2.50 \pm 1.19$ & $1.50 \pm 0.65 \mathrm{a}$ & $1.00 \pm 0.58 \mathrm{a}$ \\
\hline XPU & $0.75 \pm 0.48$ & $1.00 \pm 0.71 \mathrm{~cd}$ & $0.50 \pm 0.50 b$ & $3.00 \pm 1.47$ & $0.25 \pm 0.25 \mathrm{a}$ & $1.25 \pm 0.25 \mathrm{a}$ \\
\hline
\end{tabular}

Notes: The number of replicates per treatment was four. Means within a column followed by the same letter are not significantly different at $P<0.05$.

* PT, pre foliar and granular application (21 days after planting).

14 DPT, days after foliar and granular application (35 days after planting).

$\$ 28$ DPT, days after foliar and granular application (49 days after planting).

W, water; G, Gaucho 600; E, Entrust WP; M-1, M-1 (25 g/L); M-2, M-2 (50 g/L); Met, Met52 EC; My, Mycotrol ESO; My + Met, Mycotrol ESO + Met52 EC; My+ Az, Mycotrol ESO + Aza-Direct; My + E, Mycotrol ESO + Entrust WP; My + G, Mycotrol ESO + Gaucho 600; Met + Az, Met52 EC + Aza-Direct; Met + E, Met52 EC + Entrust WP; Met + G, Met52 EC + Gaucho 600; XPE, Xpectro OD; Bi, BioCeres GR; XPU, Xpulse OD. 
Table 6. Wireworm catch per baited trap on wheat seedling plots treated with biopesticides or synthetic insecticides at the two study locations of Montana, 2016.

\begin{tabular}{lccccc}
\hline & \multicolumn{2}{c}{ Ledger } & & \multicolumn{2}{c}{ Valier } \\
\cline { 2 - 3 } \cline { 5 - 6 } Treatment & PT $^{*}$ & $28 \mathrm{DPT}^{\dagger}$ & & $\mathrm{PT}^{\dagger}$ & $28 \mathrm{DPT}^{\dagger}$ \\
\hline $\mathrm{W}$ & $2.25 \pm 1.44$ & $0.75 \pm 0.75 \mathrm{a}$ & & $0.00 \pm 0.00$ & $1.00 \pm 0.00 \mathrm{a}$ \\
$\mathrm{G}$ & $0.75 \pm 0.48$ & $0.00 \pm 0.00 \mathrm{a}$ & & $0.25 \pm 0.25$ & $0.00 \pm 0.00 \mathrm{a}$ \\
$\mathrm{E}$ & $1.00 \pm 0.41$ & $0.00 \pm 0.00 \mathrm{a}$ & & $0.25 \pm 0.25$ & $0.25 \pm 0.00 \mathrm{a}$ \\
$\mathrm{AZ}$ & $0.75 \pm 0.48$ & $0.00 \pm 0.00 \mathrm{a}$ & & $0.50 \pm 0.50$ & $1.00 \pm 0.71 \mathrm{a}$ \\
$\mathrm{P}$ & $0.50 \pm 0.50$ & $0.75 \pm 0.48 \mathrm{a}$ & & $0.50 \pm 0.50$ & $0.25 \pm 0.25 \mathrm{a}$ \\
$\mathrm{GE}$ & $0.25 \pm 0.25$ & $0.00 \pm 0.00 \mathrm{a}$ & & $0.00 \pm 0.00$ & $0.25 \pm 0.25 \mathrm{a}$ \\
$\mathrm{V}$ & $4.25 \pm 4.25$ & $0.50 \pm 0.50 \mathrm{a}$ & & $0.00 \pm 0.00$ & $1.25 \pm 0.48 \mathrm{a}$ \\
$\mathrm{MM}$ & $2.00 \pm 1.35$ & $0.25 \pm 0.25 \mathrm{a}$ & & $0.00 \pm 0.00$ & $1.25 \pm 0.75 \mathrm{a}$ \\
$\mathrm{MC}$ & $0.50 \pm 0.50$ & $0.25 \pm 0.25 \mathrm{a}$ & & $0.75 \pm 0.48$ & $0.50 \pm 0.50 \mathrm{a}$ \\
$\mathrm{XPE}$ & $0.75 \pm 0.25$ & $0.00 \pm 0.00 \mathrm{a}$ & & $0.25 \pm 0.25$ & $0.50 \pm 0.50 \mathrm{a}$ \\
$\mathrm{T} 1$ & $0.00 \pm 0.00$ & $0.00 \pm 0.00 \mathrm{a}$ & & $0.25 \pm 0.25$ & $0.25 \pm 0.25 \mathrm{a}$ \\
T2 & $1.25 \pm 0.95$ & $0.00 \pm 0.00 \mathrm{a}$ & $0.00 \pm 0.00$ & $0.75 \pm 0.48 \mathrm{a}$ \\
\end{tabular}

Notes: The number of replicates per treatment was four. Means within a column followed by the same letter are not significantly different at $P<0.05$.

* PT, pre foliar and granular application (21 days after planting).

$\dagger 28$ DPT, days after foliar and granular application (49 days after planting).

W, water; G, Gaucho 600; E, Entrust WP; AZ, Aza-Direct; P, PyGanic 1.4 EC; GR, Grandevo SC; V, Venerate XC; MM, Met52 microsclerotial granules; MC, Met52 corn grit granules; XPE, Xpectro OD; T1, Thimet 20-G (2.80 kg/ha); T2, Thimet $20-\mathrm{G}(5.61 \mathrm{~kg} / \mathrm{ha})$.

Fig. 3. Wheat yield produced in different treatments at the two study locations of Montana, (mean \pm standard error (SE)), 2015. The number of replicates per treatment was four. Bars bearing the same letters are not significantly different (Fisher's least significant test, $P>0.05$ ). W, water; G, Gaucho 600; E, Entrust WP; M-1, M-1 (25 g/L); M-2, M-2 (50 g/L); Met, Met52 EC; My, Mycotrol ESO; My+ Met, Mycotrol ESO+Met52 EC; $\mathrm{My}+\mathrm{Az}$, Mycotrol ESO + Aza-Direct; My+E, Mycotrol ESO+Entrust WP; My+ G, Mycotrol ESO + Gaucho 600; Met + Az, Met52 EC + Aza-Direct; Met +E, Met52 EC+Entrust WP; Met + G, Met52 EC + Gaucho 600; XPE, Xpectro OD; Bi, BioCeres GR; XPU, Xpulse OD.

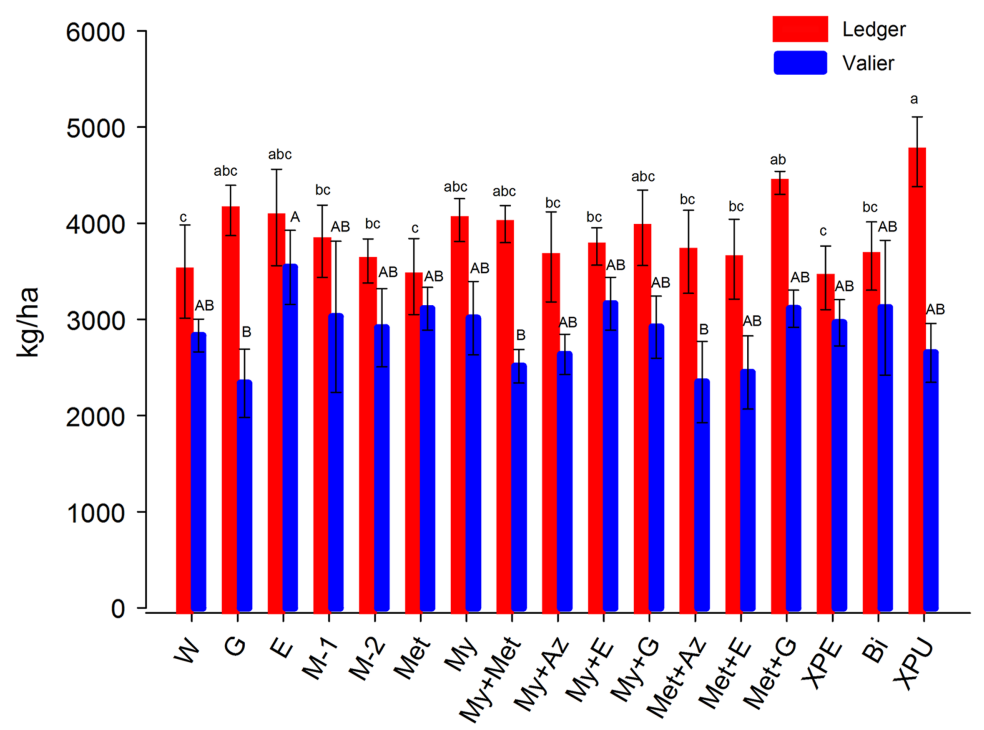

Treatments 
Fig. 4. Wheat yield produced in different treatments at the two study locations of Montana, (mean \pm standard error (SE)), 2016. The number of replicates per treatment was four. Bars bearing the same letters are not significantly different (Fisher's least significant test, $P>0.05$ ). W, water; G, Gaucho 600; E, Entrust WP; AZ, Aza-Direct; P, PyGanic 1.4 EC; GR, Grandevo SC; V, Venerate XC; MM, Met52 microsclerotial granules; MC, Met52 corn grit granules; XPE, Xpectro OD; T1, Thimet 20-G (2.80 kg/ha); T2, Thimet 20-G $(5.61 \mathrm{~kg} / \mathrm{ha})$.

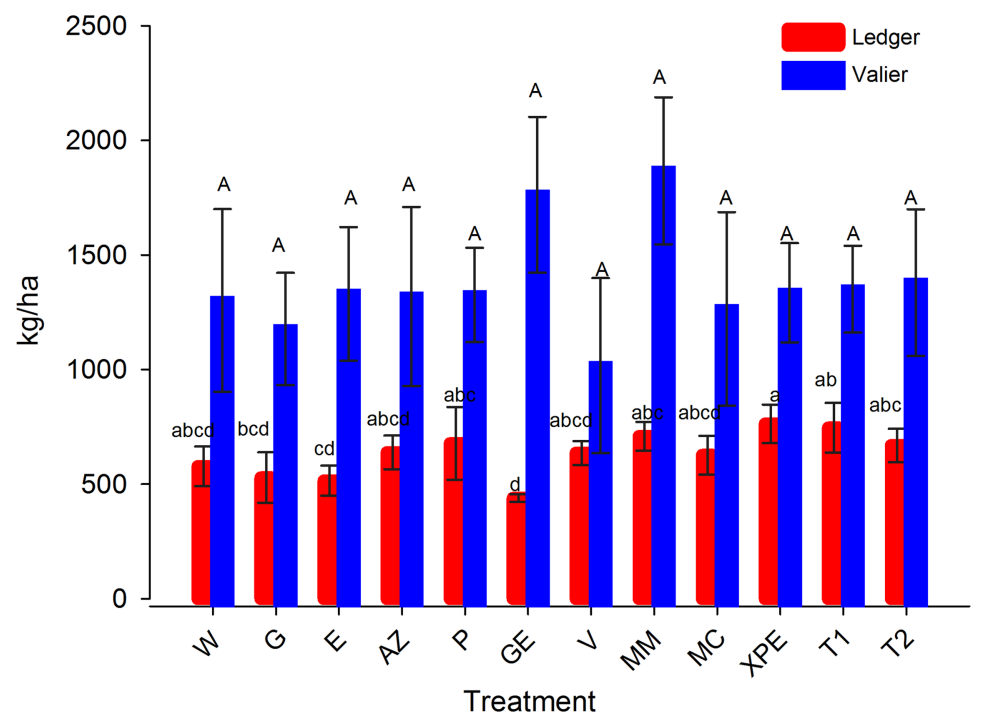

of other products (AgInfomatics 2014), and in our 2015 trial it provided effective stand protection (as determined by percent wheat survival) at Ledger location. At the Valier location, plant stand counts were nearly twofold higher in imidacloprid treated plot compared with water control after treatment application but without significant difference. Our observations suggest that imidacloprid provided wheat seedlings early season protection because wireworms become moribund after exposure to this seed treatment (van Herk et al. 2007, 2008; Vernon et al. 2008, 2009). The exposure of wireworms to neonicotinoid (i.e., imidacloprid, clothianidin) insecticides causes prolonged periods of subacute toxicity (without persistence) characterised by immobility, loss of coordination, and inability to feed after which larvae recover (van Herk et al. 2007, 2008; Vernon et al. 2008).

Among several biopesticide treatments in the 2015 study, we found that entomopathogenic fungus treatments alone or in combination with imidacloprid resulted in significantly higher plant stand compared with the control. However, this effect was found only in one of four site-years. These results were comparable with that of the imidacloprid treatment. The impact of similar types of treatments on plant stand density has been examined previously (Ester and Huiting 2007; Kabaluk and Ericsson 2007; Reddy et al. 2014). For example, Kabaluk and Ericsson (2007) reported that application of M. anisopliae (F52) alone resulted in significant increase in stand density of field corn infested with wireworms $(A$. obscurus) but did not enhance stand density when this fungus was combined with spinosyn. On the other hand, a study by Ester and Huiting (2007) found no effect from use of B. bassiana or its combination with imidacloprid on the stem density in potato fields infested with Agriotes species, even though a significant reduction in wireworm damage was observed in potato tubers with both treatments.

Limited information exists regarding the impact of entomopathogenic fungi alone or in combination with imidacloprid on wheat stand density, except for the study by Reddy et al. (2014). The authors found that the use of several entomopathogenic fungi including $M$. brunneum F52 granules and B. bassiana GHA granules resulted in significantly higher wheat seedling protection compared with the control, in spring wheat infested by two wireworm species: $L$. californicus 
and H. bicolor. This result is consistent with our study, suggesting that entomopathogenic fungi such as B. bassiana GHA (Mycotrol), B. bassiana ANT-03 (BioCeres GR), and M. brunneum F52 have the ability to protect wheat plant seedlings from wireworm damage.

No previous reports have examined the effect of combining entomopathogenic fungi and imidacloprid for wheat seedling protection. Our results suggest that imidacloprid and entomopathogenic fungi can work synergistically, such as the combination of imidacloprid and M. brunneum, which provided better wheat stand protection against wireworm damage than imidacloprid alone. The wheat yields support this observation, with significantly or at least numerically higher yields than the control when spring wheat was treated with combined applications of imidacloprid and M. brunneum or imidacloprid and $B$. bassiana GHA, respectively. Moreover, wheat plots treated with $B$. bassiana and azadirachtin mixture product (Xpulse) provided significantly higher grain yield compared with controls at Ledger. Our data indicate this product has some possibility for use against wireworms.

In contrast to the 2015 study, in 2016 there was a lack of any significant effect of biopesticides, including imidacloprid or other pesticide treatments, on stand counts compared with the control. The reason for this phenomenon is unclear, but abiotic factors such as temperature, rainfall and the planting date may have influenced wireworm activity beneath the soil. Campbell (1937) and Milosavljevic et al. (2016) reported that lower temperature and rainfall during the growing season hindered the movement of wireworm larvae towards the soil surface, thereby reducing feeding activity. The authors also reported that in general, wireworm-feeding activity begins at soil temperatures of $10^{\circ} \mathrm{C}$, with highest activity at $15-18^{\circ} \mathrm{C}$. Higher soil moisture further enhanced wirewormfeeding activity. In our study, lower average temperature and precipitation were recorded in 2016 $\left(12^{\circ} \mathrm{C}\right.$ and $\left.15 \mathrm{~mm}\right)$ than during $2015\left(17^{\circ} \mathrm{C}\right.$ and $136 \mathrm{~mm}$ of rain) (Natural Resources Conservation Service 2017). These factors could have led to less wireworm activity in 2016, a possibility further supported by our results, which found a low decline rate in wheat seeding plant counts irrespective of treatment and almost no wireworms in traps after treatment applications, in contrast to 2015.
Surprisingly, we found significantly higher wireworm populations in treatments with insect pathogenic fungi, spinosyn (Entrust) alone, or insect pathogenic fungi + spinosyn compared with water control or imidacloprid treatments. These findings, especially for insect pathogenic fungi treatments, appeared to be in disagreement with the findings reported by Reddy et al. (2014), which found significantly lower number of wireworms in entomopathogenic fungus treatments than in the control treatment. However, this result did not occur consistently and only in one out of four site-years. This inconsistent performance of treatments may have been caused by non-uniform wireworm distribution in the plots or lack of fungal treatments due to abiotic factors such as soil temperature and moisture. Additional studies are necessary to resolve the present inconsistencies.

No other reports directly comparing insect pathogenic fungus effects on wireworms in a spring wheat crop are available. Kabaluk and Ericsson (2007) reported that $A$. obscurus were repelled by M. anisopliae-contaminated soil in a corn trial, at a rate that increased with conidial concentration in the soil. Several studies have examined the interaction of beetle/weevil larvae with fungal pathogens in the soil or rhizosphere. Kepler and Bruck (2006) stated that black vine weevil Otiorhynchus sulcatus (Fabricius) (Coleoptera: Curculionidae) larvae were significantly more attracted to Norway spruce tree (Picea abies Linnaeus; Pinaceae) roots growing in M. anisopliae-inoculated potting media than plants grown in un-inoculated media. Similar findings were reported by Villani et al. (1994), who observed that Japanese beetles, Popillia japonica Newman (Coleoptera: Scarabaeidae), were more attracted to oviposit in bare soil treated with $M$. anisopliae than non-inoculated soil, possibly in response to $\mathrm{CO}_{2}$ released during mycelial growth. Currently, no information is available on the behaviour in relation to fungus of the wireworm species (L. californicus, H. bicolor, and A. mellilus) commonly found in Montana agriculture soils. Our findings suggest that soil insect pest behaviour such as wireworms in connection with fungal exposure should be taken into consideration when developing integrated pest management strategies.

In conclusion, although variability between years and between sites was observed in the present study, the overall results indicate that insect pathogenic fungi alone or in combination with 
imidacloprid could be used for the management of wireworms in spring wheat in the Golden Triangle area of Montana. However, cost/benefit studies will be required if the application of biopesticide products are economical and sustainable for spring wheat growers in the Golden Triangle.

\section{Acknowledgements}

This work was supported by the Montana Wheat and Barley and United States Department of Agriculture National Institute of Food and Agriculture, Multistate Project S-1070 and, the Working Group on Improving Microbial Control of Arthropod Pests Covering Research in Montana [accession number 232056]. Any opinions, findings, conclusions, or recommendations expressed in this publication are those of the authors and do not necessarily reflect the view of the National Institute of Food and Agriculture (NIFA) or the United States Department of Agriculture (USDA). We would like to thank John H. Miller, Julie Prewett, Dawson Berg, and Kristal Judisch for their assistance with the fieldwork.

\section{References}

Adhikari, A. and Reddy, G.V.P. 2017. Evaluation of trap crops for the management of wireworms in spring wheat in Montana. Arthropod-Plant Interaction, 6: 755-766.

AgInfomatics. 2014. The value of neonicotinoids in North American agriculture: estimated impact of neonicotinoid insecticides on pest management practices and costs for U.S. corn, soybean, wheat, cotton, and sorghum farmers. AgInfomatics, I-20Oct-2014. Available from http://aginfomatics. com/uploads/3/4/2/2/34223974/executive_summary_ neonicotinoids.pdf [accessed 10 October 2017].

Ansari, M., Evans, M., and Butt, T. 2009. Identification of pathogenic strains of entomopathogenic nematodes and fungi for wireworm control. Crop Protection, 28: 269-272.

Barsics, F., Haubruge, E., and Verheggen, F.J. 2013. Wireworms' management: an overview of the existing methods, with particular regards to Agriotes spp. (Coleoptera: Elateridae). Insects, 4: 117-152.

Campbell, R.E. 1937. Temperature and moisture preferences of wireworms. Ecology, 18: 479-489.

Chandler, D., Bailey, A.S., Tatchell, G.M., Davidson, G., Greaves, J., and Grant, W.P. 2011. The development, regulation and use of biopesticides for integrated pest management. Philosophical Transactions of the Royal Society of London B: Biological Sciences, 366: 1987-1998.
Desneux, N., Decourtye, A., and Delpuech, J.M. 2007. The sublethal effects of pesticides on beneficial arthropods. Annual Review of Entomology, 52: 81-106.

Elliott, J.E, Birmingham, A.L, Wilson, L.K., McAdie, M., Trudeau, S., and Mineau, P. 2008. Fonofos poisons raptors and waterfowl several months after granular application. Environmental Toxicology and Chemistry, 27: 452-460.

Ericsson, J.D., Kabaluk, J.T., Goettel, M.S., and Myers, J.H. 2007. Spinosad interacts synergistically with the insect pathogen Metarhizium anisopliae against the exotic wireworms Agriotes lineatus and Agriotes obscurus (Coleoptera: Elateridae). Journal of Economic Entomology, 100: 31-38.

Ester, A. and Huiting, H. 2007. Controlling wireworms (Agriotes spp.) in a potato crop with biologicals. International Organisation for Biological and Integrated Control, West Palaearctic Regional Section Bulletin, 30: 189-196.

Etzler, F.E., Wanner, K.W., Morales-Rodriguez, A., and Ivie, M.A. 2014. DNA barcoding to improve the species-level management of wireworms (Coleoptera: Elateridae). Journal of Economic Entomology, 107: 1476-1485.

Jackson, T., Alves, S., and Pereira, R. 2000. Success in biological control of soil-dwelling insects by pathogens and nematodes. In Biological control: measures of success. Edited by G. Gurr and S. Wratten. Kluwer Academic Publishers, Dordrecht, The Netherlands. Pp. 271-296.

Jaronski, S.T. 2010. Ecological factors in the inundative use of fungal entomopathogens. Biocontrol, 55: 159-185.

Kabaluk, J.T. and Ericsson, J.D. 2007. Seed treatment increases yield of field corn when applied for wireworm control. Agronomy Journal, 99: 1377-1381.

Kabaluk, J.T., Goettel, M., Erlandson, M., Ericsson, J., Duke, G., and Vernon, R.S. 2005. Metarhizium anisopliae as a biological control for wireworms and a report of some other naturally-occurring parasites. International Organisation for Biological and Integrated Control, West Palaearctic Regional Section Bulletin, 28: 109-115.

Keiser, A., Häberli, M., and Stamp, P. 2012. Drycore appears to result from an interaction between Rhizoctonia solani and wireworm (Agriotes spp.) evidence from a 3-year field survey. Potato Research, 55: 59-67.

Kepler, R.M. and Bruck, D.J. 2006. Examination of the interaction between the black vine weevil (Coleoptera: Curculionidae) and an entomopathogenic fungus reveals a new tritrophic interaction. Environmental Entomology, 35: 1021-1029.

Koch, R., Burkness, E., Hutchison, W., and Rabaey, T. 2005. Efficacy of systemic insecticide seed treatments for protection of early-growth-stage snap beans from bean leaf beetle (Coleoptera: Chrysomelidae) foliar feeding. Crop Protection, 24: 734-742. 
Kuhar, T.P. and Alvarez, J.M. 2008. Timing of injury and efficacy of soil-applied insecticides against wireworms on potato in Virginia. Crop Protection, 27: 792-798.

Ladurner, E., Quentin, U., Franceschini, S., Benuzzi, M., and Ehlers, R. 2009. Efficacy evaluation of the entomopathogenic fungus Beauveria bassiana strain ATCC 74040 against wireworms (Agriotes spp.) on potato. International Organisation for Biological and Integrated Control, West Palaearctic Regional Section Bulletin, 45: 445-448.

Lanning, S.P., Carlson, G.R., Lamb, P.F., Nash, D., Wichman, D.M., Kephart, K.D., et al. 2011. Registration of 'Duclair' Hard Red Spring Wheat. Journal of Plant Registrations, 5: 349-352.

Marske, K.A. and Ivie, M.A. 2003. Beetle fauna of the United States and Canada. Coleopterists Bulletin, 57: 495-503.

Milosavljevic, I., Esser, A.D., and Crowder, D.W. 2016. Seasonal population dynamics of wireworms in wheat crops in the Pacific Northwestern United States. Journal of Pest Science, 90: 77-86.

Natural Resources Conservation Service. 2017. United States Department of Agriculture Natural Resources Conservation Service. Weather report. Available from https://wcc.sc.egov.usda.gov/nwcc/site?sitenum= 2117 [accessed 10 October 2017].

Nault, B.A., Straub, R.W., and Taylor, A.G. 2006. Performance of novel insecticide seed treatments for managing onion maggot (Diptera: Anthomyiidae) in onion fields. Crop Protection, 25: 58-65.

Nault, B.A., Taylor, A.G., Urwiler, M., Rabaey, T., and Hutchison, W.D. 2004. Neonicotinoid seed treatments for managing potato leafhopper infestations in snap bean. Crop Protection, 23: 147-154.

Parker, W.E. 2005. Practical implementation of a wireworm management strategy - lessons from the UK potato industry. International Organisation for Biological and Integrated Control, West Palaearctic Regional Section Bulletin, 28: 87-90.

Parker, W.E. and Howard, J.J. 2001. The biology and management of wireworms (Agriotes spp.) on potato with particular reference to the UK. Agricultural and Forest Entomology, 3: 85-98.

Popov, C., Barbulescu, A., Trotus, E., Vasilescu, S., and Bucurean, E. 2001. Control of wireworms by seed treatment in Romania. Romanian Agricultural Research, 15: 69-75.

Potter, D.A., Powell, A.J., Spicer, P. G., and Williams, D.W. 1996. Cultural practices affect root-feeding white grubs (Coleoptera: Scarabaeidae) in turfgrass. Journal of Economic Entomology, 89: 156-164.

Reddy, G.V.P. and Antwi, F.B. 2016. Toxicity of natural insecticides on the larvae of wheat head armyworm, Dargida diffusa (Lepidoptera: Noctuidae). Environmental Toxicology and Pharmacology, 42: 156-162.

Reddy, G.V.P., Antwi, F.B., Shrestha, G., and Kuriwada, T. 2016. Evaluation of toxicity of biorational insecticides against larvae of the alfalfa weevil. Toxicology Reports, 3: 473-480.
Reddy, G.V.P. and Tangtrakulwanich, K. 2014. Potential application of pheromones in monitoring, mating disruption, and control of click beetles (Coleoptera: Elateridae). ISRN Entomology, 2014: 531061.

Reddy, G.V.P., Tangtrakulwanich, K., Wu, S., Miller, J.H., Ophus, V.L., Prewett, J., and Jaronski, S. 2014. Evaluation of the effectiveness of entomopathogens for the management of wireworms (Coleoptera: Elateridae) on spring wheat. Journal of Invertebrate Pathology, 120: 43-49.

Ritter, C. and Richter, E. 2013. Control methods and monitoring of Agriotes wireworms (Coleoptera: Elateridae). Journal of Plant Disease Protection, 120: 4-15.

SAS Institute. 2015. SAS 9.4. In-database products, user's guide, 5th edition. SAS Publishers, Cary, North Carolina, United States of America.

Shrestha, G., Enkegaard, A., and Stenberg, T. 2015. Laboratory and semi-field evaluation of Beauveria bassiana (Ascomycota: Hypocreales) against the lettuce aphid, Nasonovia ribisnigri (Hemiptera: Aphididae). Biological Control, 85: 37-45.

Tharp, C.I., Blodgett, S.L., and Jaronski, S. 2005. Control of wireworm (Elateridae) with the microbial "Metarhizium F52" in potatoes near Huntley, MT, field season 2005. Cooperative Extension, Department of Animal and Range Science, Montana State University, 392: 33-35.

Thomas, C.A. 1940. The biology and control of wireworms. A review of the literature. Pennsylvania State College Bulletin, 392: 1-90.

Traugott, M., Benefer, C.M., Blackshaw, R.P., van Herk, W.G., and Vernon, R.S. 2015. Biology, ecology, and control of elaterid beetles in agricultural land. Annual Review of Entomology, 60: 313-334.

van Herk, W.G. and Vernon, R.S. 2014. Click beetles and wireworms (Coleoptera: Elateridae) of Alberta, Saskatchewan, and Manitoba. In Arthropods of Canadian grasslands (volume 4): biodiversity and systematics part 2. Edited by D.J. Giberson and H.A. Cárcamo. Biological Survey of Canada, Ottawa, Ontario, Canada. Pp. 87-117.

van Herk, W.G., Vernon, R.S., Clodius, M., Harding, C., and Tolman, J. 2007. Mortality of five wireworm species (Coleoptera: Elateridae), following topical application of clothianidin and chlorpyrifos. Journal of Entomological Society of British Colombia, 104: 55-64.

van Herk, W.G, Vernon, R.S., Tolman, J., and Saavedra, H.O. 2008. Mortality of a wireworm, Agriotes obscurus (Coleoptera: Elateridae), after topical application of various insecticides. Journal of Economic Entomology, 101: 375-383.

Vernon, R.S., Clodius, M., and Harding, C. 2009. Wireworm management I: stand protection versus wireworm mortality with wheat seed treatments. Journal of Economic Entomology, 102: 2126-2136.

Vernon, R.S. and van Herk, W.G. 2013. Wireworms as pests of potato. In Insect pests of potato: global perspectives on biology and management. Edited by P. Giordanengo, C. Vincent, and A. Alyokhin. Academic, Elsevier, Amsterdam, The Netherlands. Pp. 103-164. 
Vernon, R.S., van, Herk, W.G., Tolman, J., Saavedra, H.O., Clodius, M., and Gage, B. 2008. Transitional sublethal and lethal effects of insecticides after dermal exposures to five economic species of wireworms (Coleoptera: Elateridae). Journal of Economic Entomology, 101: 365-374.

Villani, M.G., Krueger, S.R., Schroeder, P.C., Consolie, F., Consolie, N.H., Preston-Wilsey, L.M., and Donald, W.R. 1994. Soil application effects of Metarhizium anisopliae on Japanese beetle (Coleoptera: Scarabaeidae) behavior and survival in turfgrass microcosms. Environmental Entomology, 23: 502-513.
Wilde, G., Roozeboom, K., Ahmad, A., Claassen, M., Gordon, B., Heer, W., et al. 2007. Seed treatment effects on early-season pests of corn and on corn growth and yield in the absence of insect pests. Journal of Agriculture Urban Entomology, 24: 177-193.

Wilde, G., Roozeboom, K., Claassen, M., Janssen, K., and Witt, M. 2004. Seed treatment for control of earlyseason pests of corn and its effect on yield. Journal of Agriculture Urban Entomology, 21: 75-85.

Willis, R.B., Abney, M.R., Holmes, G.J., Schultheis, J.R., and Kennedy, G.G. 2010. Influence of preceding crop on wireworm (Coleoptera: Elateridae) abundance in the coastal plain of North Carolina. Journal of Economic Entomology, 103: 2087-2093. 